\title{
ASSESSMENT OF FREQUENCY SUPPORT SERVICES AND PROCUREMENT METHODS IN CONTINENTAL EUROPE AND REPUBLIC OF MACEDONIA
}

\author{
Anželika Ivanova, Petar Krstevski, Aleksandra Krkoleva-Mateska \\ Faculty of Electrical Engineering and Information Technologies, \\ "Ss. Cyril and Methodius" University in Skopje, \\ Rugjer Bošković bb, P.O. box 574, 1001 Skopje, Republic of Macedonia \\ anzelikaivanova@gmail.com
}

\begin{abstract}
A b s t r a c t: One of the very important aspects of power system development is improving the stability of the system, which can be disrupted from the high penetration of renewable energy sources. This increases the need for frequency support (FS) services. An improvement of the current services for FS and procurement methods for these services is already being implemented in European countries. The aim of this research is to assess the current conditions of FS markets in Continental Europe and Macedonia and to underline the main steps that should be taken for the improvement of FS services and procurement methods in Macedonia. Furthermore, it highlights the challenges for FS market development.
\end{abstract}

Key words: frequency support services; reserves; procurement methods; electricity market

\section{ПРОЦЕНА НА ДОПОЛНИТЕЛНИ УСЛУГИ ЗА РЕГУЛАЦИЈА НА ФРЕКВЕНЦИЈАТА И МЕТОДИТЕ ЗА НИВНА НАБАВКА ВО ЗЕМЈИТЕ ОД КОНТИНЕНТАЛНА ЕВРОПА И ВО РЕПУБЛИКА МАКЕДОНИЈА}

\begin{abstract}
А п с т р а к т: Еден од најважните аспекти на развивањето на електричната мрежа е стабилноста на мрежата, која може да биде нарушена поради зголемената интеграција на обновливите извори на енергија Како последица на тоа се зголемува потребата од дополнителни услуги за регулација на фреквенцијата. Подобрувања на овие услуги и методите за нивна набавка веќе се имплементираат во земјите од Европа. Целта на ова истражување е да се направи преглед на сегашната состојба на пазарите на дополнителни услуги за регулација на фреквенцијта во земјите од континентална Европа и во Македонија и да се прикажат главните чекори кои треба да се преземат за подобрување на овие услуги и, како и методите за нивна набавка во Македонија. Дополнително се прикажани и бариерите за воспоставување пазар на дополнителни услуги.
\end{abstract}

Клучни зборови: дополнителни услуги; регулација на фреквенција; методи на набавка; пазар на електрична енергија

\section{INTRODUCTION}

The stability of a power system is one of the most important aspects for reliable supply of electricity. When generation and consumption are not balanced, the frequency of the system deviates from its set value and the stability is disrupted. This is especially the case with the integration of intermittent generation in the system. This distruption must be addressed with the help of FS services.
With the development of the power system, there should be an improvement of the current services for FS and procurement methods, in order to meet the new needs of the system.

The European Network of Transmission System Operators for Electricity (ENTSO-E) has already set in motion improvements of FS services, by updating the definitions and requirements in the Network Code on Load Frequency Control and Reserves (LFCR) [1]. The code also enables 
cross-border exchange for these services. There are several initiatives for cross-border exchanges, as listed in [2].

Republic of Macedonia, as a member of ENTSO-E, should follow these improvements, but they have not been implemented yet.

The Study for Estimating Expenses from Integration of Renewable Energy Sources (RES) in the Power System in R. Macedonia [3] has shown that RES integration would not considerably increase the requirements for FS in R. Macedonia, but there is still a substantial need of these services for balancing of the current conventional generation. This highlights the necessity for improvement of the current practices.

The aim of this research is to assess the current conditions of FS markets in Continental Europe and Republic of Macedonia and to underline the important steps that should be taken for the improvement of FS procurement methods in R. Macedonia. The first section explains the ENTSO-E definitions of the FS services and the latest updates and requirements for these services. The second section briefly summarizes the procurement practices in several countries in Continental Europe (CE). The definitions of the FS services and procurement methods in R. Macedonia are given in the third section, followed by the recommendations for their improvement and the challenges for FS market development. The forth section gives the conclusions from the research.

\section{ENTSO-E DEFINITIONS FOR FREQUENCY SUPPORT SERVICES}

The definitions of services for FS provided in national guidelines differ based on which European country is in question.

In the member countries of ENTSO-E CE Regional Group, the definitions are provided in the Continental Europe Operation Handbook [4] that also sets the requirements. For the Nordic synchronous area, the definitions and requirements are set by the System Operation Agreement [5]. Moreover, UK and Ireland have their national definitions for these services.

The aim to achieve a single European electricity market includes the synchronization of the frequency support markets. Therefore, the different frequency support products should be harmonized. This has been done with the LFCR [1] from ENTSO-E. An update on this code is implemented in the System Operation Guideline [6] of ENTSO$\mathrm{E}$, which is still pending approval from the European Commission.

The emphasis in this section are the requirements for the CE region.

\section{Frequency containment reserve ( $F C R)$}

The FCR is an automatically activated reserve that aims at containing the deviation of the system frequency within a pre-defined range, after the occurrence of an incident.

The determination of FCR capacity for a Synchronous Area and the shares for each Transmission System Operator (TSO) is an obligation of the TSOs [1], [6]. These capacities must be recalculated on annual basis. The dimensioning of the FCR is based on a risk assessment criterion having in consideration the load and generation inertia and synthetic inertia patterns.

The FCR capacity should cover the reference incident of the synchronous area. For CE, the reference incident is the absolute value of the largest imbalance that may result from an instantaneous change of active power of one or two Power Generating Modules or one or two HVDC interconnectors connected to the same electrical node or the maximum instantaneous loss of Active Power consumption due to the tripping of one or two connections points [1]. In [6], the reference incident for CE is set on $3000 \mathrm{MW}$ in both positive and negative direction.

The shares for each TSO are based on the sum of the net generation and consumption of its area divided by the sum of net generation and consumption of the synchronous area over a period of one year [1].

The technical minimum requirements for FCR in CE synchronous area are given in Table 1 [1].

Table 1

FCR technical minimum requirements for CE synchronous area [1]

\begin{tabular}{ll}
\hline \hline $\begin{array}{l}\text { Minimum accuracy of frequency } \\
\text { measurement }\end{array}$ & $\begin{array}{l}10 \mathrm{mHz} \text { or the } \\
\text { industrial standard if } \\
\text { better }\end{array}$ \\
$\begin{array}{l}\text { FCR Full Activation Time } \\
\begin{array}{l}\text { FCR Full Activation Frequency } \\
\text { Deviation }\end{array}\end{array}$ \\
\hline \hline
\end{tabular}




\section{Frequency restoration reserve (FRR)}

FRR is the active power reserve activated to restore system frequency to its nominal value or to restore the balance to the scheduled value in the case of more than one Load Frequency Control (LFC) area. The FRR can be activated automatically (FRR-a) or manually (FRR-m), from a single reserve providing unit or a reserve providing group.

The TSOs of the synchronous area are responsible for determining the required FRR capacity [1], [6]. The calculations are performed on an annual basis, based on consecutive historical records of LFC block imbalance values.

The TSOs are also obliged to determine the ratio of FRR-a and FRR-m capacity and FRR-a and FRR-m full activation time. The maximum of both full activation times should be at most the time to restore frequency, which for the $\mathrm{CE}$ region is 15 minutes [1], [6]. The delay that is permitted in the activation of the FRR-a is at most $30 \mathrm{~s}$.

The FRR capacity is determined for both positive and negative direction separately, such that it is not smaller than the positive or negative dimensioning incident of the LFC block, respectively. The dimensioning incident is the largest imbalance that may result from an instantaneous change in active power of a single generating module, demand facility, HVDC interconnector or a tripping of an AC line [1]. The FRR should be able to cover $99 \%$ of all positive and negative imbalances in the LFC block [1].

\section{Replacement reserve $(R R)$}

$\mathrm{RR}$ is the active power reserve needed to restore and support the required FRR level for additional system imbalances. This reserve is activated anually. The TSOs must ensure that the RR reserve is sufficient to cover the FRR in both positive and negative directions [1], [6].

RR should be activated 15 minutes after an incident and sustained for up to several hours if a sustained activation of FRR is expected.

\section{FREQUENCY SUPPORT PROCUREMENT PRACTICES IN CONTINENTAL EUROPE}

The countries in Europe have different methods of procurement for FS services. This section aims to give a short overview of the procurement methods in several CE countries.

Many of the countries in CE still use the UCTE services specifications. For a clearer representation of the FS services and procurement methods, the FS services are classified based on the ENTSO-E definitions and given in Table 2 for FCR, in Table 3 for FRR-a and in Table 4 for FRR-m and RR [7]. Furthermore, the procurement methods, the gate closing time and minimum offer are given.

Table 2

Summary of procurement methods for FCR

\begin{tabular}{|c|c|c|c|c|c|c|c|}
\hline $\begin{array}{l}\text { Reserve type by } \\
\text { ENTSO-E [1], [6] }\end{array}$ & Parameters & The Netherlands & Belgium & France & Germany & Spain & Portugal \\
\hline \multirow{4}{*}{$\begin{array}{l}\text { Frequency } \\
\text { containment } \\
\text { reserve (FCR) }\end{array}$} & $\begin{array}{l}\text { Reserve type } \\
\text { by country }\end{array}$ & Primary reserve & $\begin{array}{l}\text { Primary } \\
\text { reserve }\end{array}$ & $\begin{array}{l}\text { Primary } \\
\text { system } \\
\text { regulation }\end{array}$ & $\begin{array}{l}\text { Primary control } \\
\text { reserve }\end{array}$ & $\begin{array}{l}\text { Primary } \\
\text { control } \\
\text { reserve }\end{array}$ & $\begin{array}{l}\text { Primary } \\
\text { control } \\
\text { reserve }\end{array}$ \\
\hline & $\begin{array}{l}\text { Procurement } \\
\text { arrangement }\end{array}$ & $\begin{array}{l}\text { Recently through } \\
\text { tenders on the } \\
\text { German platform }\end{array}$ & $\begin{array}{l}\text { Short-term } \\
\text { auction or } \\
\text { long-term } \\
\text { tender }\end{array}$ & $\begin{array}{l}\text { Mandatory, } \\
\text { according to } \\
\text { AS rules }\end{array}$ & $\begin{array}{l}\text { Market auctions - } \\
\text { weekly call for } \\
\text { tender }\end{array}$ & Mandatory & Mandatory \\
\hline & $\begin{array}{l}\text { Gate closing } \\
\text { time }\end{array}$ & $\begin{array}{l}\text { Every week by } \\
\text { Tuesday at 15:00 } \\
{[8],[9]}\end{array}$ & - & - & $\begin{array}{l}\text { Every week by } \\
\text { Tuesday at 15:00 } \\
\text { [9] }\end{array}$ & - & - \\
\hline & $\begin{array}{l}\text { Minimum } \\
\text { offer }\end{array}$ & $1 \mathrm{MW}$ [9] & $1 \mathrm{MW}[10]$ & - & $1 \mathrm{MW}$ [9] & $\begin{array}{l}1.5 \% \text { of } \\
\text { nominal } \\
\text { power }\end{array}$ & - \\
\hline
\end{tabular}


Table 3

Summary of procurement methods for FRR-a

\begin{tabular}{|c|c|c|c|c|c|c|c|}
\hline $\begin{array}{l}\text { Reserve type by } \\
\text { ENTSO-E [1], [6] }\end{array}$ & Parameters & The Netherlands & Belgium & France & Germany & Spain & Portugal \\
\hline \multirow{4}{*}{$\begin{array}{l}\text { Automatic } \\
\text { frequency } \\
\text { restoration } \\
\text { reserve (FRR-a) }\end{array}$} & $\begin{array}{l}\text { Reserve type } \\
\text { by country }\end{array}$ & Secondary reserve & $\begin{array}{l}\text { Secondary } \\
\text { reserve }\end{array}$ & $\begin{array}{l}\text { Secondary } \\
\text { regulation } \\
\text { reserve }\end{array}$ & $\begin{array}{l}\text { Secondary } \\
\text { control } \\
\text { reserve }\end{array}$ & $\begin{array}{l}\text { Secondary } \\
\text { control } \\
\text { reserve }\end{array}$ & $\begin{array}{l}\text { Secondary } \\
\text { control } \\
\text { reserve }\end{array}$ \\
\hline & $\begin{array}{l}\text { Procurement } \\
\text { arrangement }\end{array}$ & Day-ahead market & $\begin{array}{l}\text { Short-term } \\
\text { auction or } \\
\text { long-term } \\
\text { tender }\end{array}$ & $\begin{array}{l}\text { Mandatory, } \\
\text { according to } \\
\text { AS rules for } \\
\text { FRR-a }\end{array}$ & $\begin{array}{l}\text { Weekly } \\
\text { auctions }\end{array}$ & $\begin{array}{l}\text { Day-ahead } \\
\text { market }\end{array}$ & $\begin{array}{l}\text { Day-ahead } \\
\text { market }\end{array}$ \\
\hline & $\begin{array}{l}\text { Gate closing } \\
\text { time }\end{array}$ & $\begin{array}{l}\text { Day before delivery } \\
\text { before } 14: 45 \text {. Can be } \\
\text { altered } 1 \text { hour before } \\
\text { delivery [11]. }\end{array}$ & $\begin{array}{l}\text { Day before } \\
\text { delivery day } \\
\text { by } 15: 00[12]\end{array}$ & - & $\begin{array}{l}\text { Before } \\
\text { Wednesday } \\
\text { every week } \\
{[13]}\end{array}$ & $\begin{array}{l}\text { At 16:00 } \\
\text { daily [14] }\end{array}$ & $\begin{array}{l}\text { In the } \\
\text { period of } \\
\text { 19:00-19:45 } \\
{[15]}\end{array}$ \\
\hline & Minimum offer & 4 MW [11] & $1 \mathrm{MW}[10]$ & - & 5 MW [13] & 10 MW [14] & - \\
\hline
\end{tabular}

Table 4

Summary of procurement methods for FRR-m and RR

\begin{tabular}{|c|c|c|c|c|c|c|c|}
\hline $\begin{array}{l}\text { Reserve type by } \\
\text { ENTSO-E [1], [6] }\end{array}$ & Parameters & The Netherlands & Belgium & France & Germany & Spain & Portugal \\
\hline \multirow{4}{*}{$\begin{array}{l}\text { Manual frequency } \\
\text { restoration reserve } \\
\text { (FRR-m) and } \\
\text { replacement } \\
\text { reserve (RR) }\end{array}$} & $\begin{array}{l}\text { Reserve type } \\
\text { by country }\end{array}$ & Tertiary reserve & Tertiary reserve & $\begin{array}{l}\text { Tertiary } \\
\text { reserve }\end{array}$ & $\begin{array}{l}\text { Minute } \\
\text { reserve }\end{array}$ & $\begin{array}{l}\text { Tertiary } \\
\text { control } \\
\text { reserve }\end{array}$ & $\begin{array}{l}\text { Tertiary } \\
\text { control } \\
\text { reserve }\end{array}$ \\
\hline & $\begin{array}{l}\text { Procurement } \\
\text { arrangement }\end{array}$ & Day-ahead market & $\begin{array}{l}\text { General framework - } \\
\text { short-term auction or } \\
\text { long-term tender; } \\
\text { Standard contracts (for } \\
\text { interruptible loads) }\end{array}$ & $\begin{array}{l}\text { Yearly } \\
\text { tender }\end{array}$ & $\begin{array}{l}\text { Daily } \\
\text { auctions }\end{array}$ & $\begin{array}{l}\text { Intraday } \\
\text { market }\end{array}$ & $\begin{array}{l}\text { Intraday } \\
\text { market }\end{array}$ \\
\hline & $\begin{array}{l}\text { Gate closing } \\
\text { time }\end{array}$ & $\begin{array}{l}\text { Bids must be deliv- } \\
\text { ered on the day be- } \\
\text { fore delivery before } \\
14: 45, \text { can be altered } \\
1 \text { hour before deliv- } \\
\text { ery [11] }\end{array}$ & $\begin{array}{l}\text { Day before delivery day } \\
\text { by } 14: 00[16]\end{array}$ & - & $\begin{array}{l}\text { At 12:00 } \\
\text { daily [17] }\end{array}$ & $\begin{array}{l}25 \text { minutes } \\
\text { before deliv- } \\
\text { ery hour [18] }\end{array}$ & $\begin{array}{l}50 \text { minutes } \\
\text { before deliv- } \\
\text { ery hour [15] }\end{array}$ \\
\hline & Minimum offer & $4 \mathrm{MW}[11]$ & $1 \mathrm{MW}$ [10] & - & $5 \mathrm{MW}$ [17] & $10 \mathrm{MW}$ [14] & - \\
\hline
\end{tabular}

Most of the countries have procurement methods that lean towards a market based procurement of AS. Examples of this can be seen in Germany and the Netherlands. In contrast, there are still cases where some of the FS services are mandatory, such as the cases in Portugal and Spain for primary (FCR) reserves. The market procurement of some FS services is still complemented by contracts on monthly and yearly basis, as it is the practice in France for FRR-m and RR.

Each service can be paid for either capacity (availability), energy (real-time use) or both. For automatic fast reserves that operate for up and down regulation so that the net energy is close to zero, only capacity payment is applicable. The practice of remuneration for used energy only is common for balancing markets (markets for manually activated reserves, i.e. FRR-m and RR). The FS services can be symmetrical for both up and down regulation (mostly for FCR) or separate for each regulation direction (FRR and RR).

In addition to the integration of European electricity markets into one Internal Electricity Market, cross border trade is also anticipated in balancing markets. This is also enabled with [1], which sets the basic requirements for reserves sharing.

The Nordic synchronous area already has an operational balancing market for more than 10 years. Many pilot projects for cross border balanc- 
ing are already being established throughout Europe. ENTSO-E has already listed several of these projects. An overview of the pilot project is shown in Fig. 1 [19].

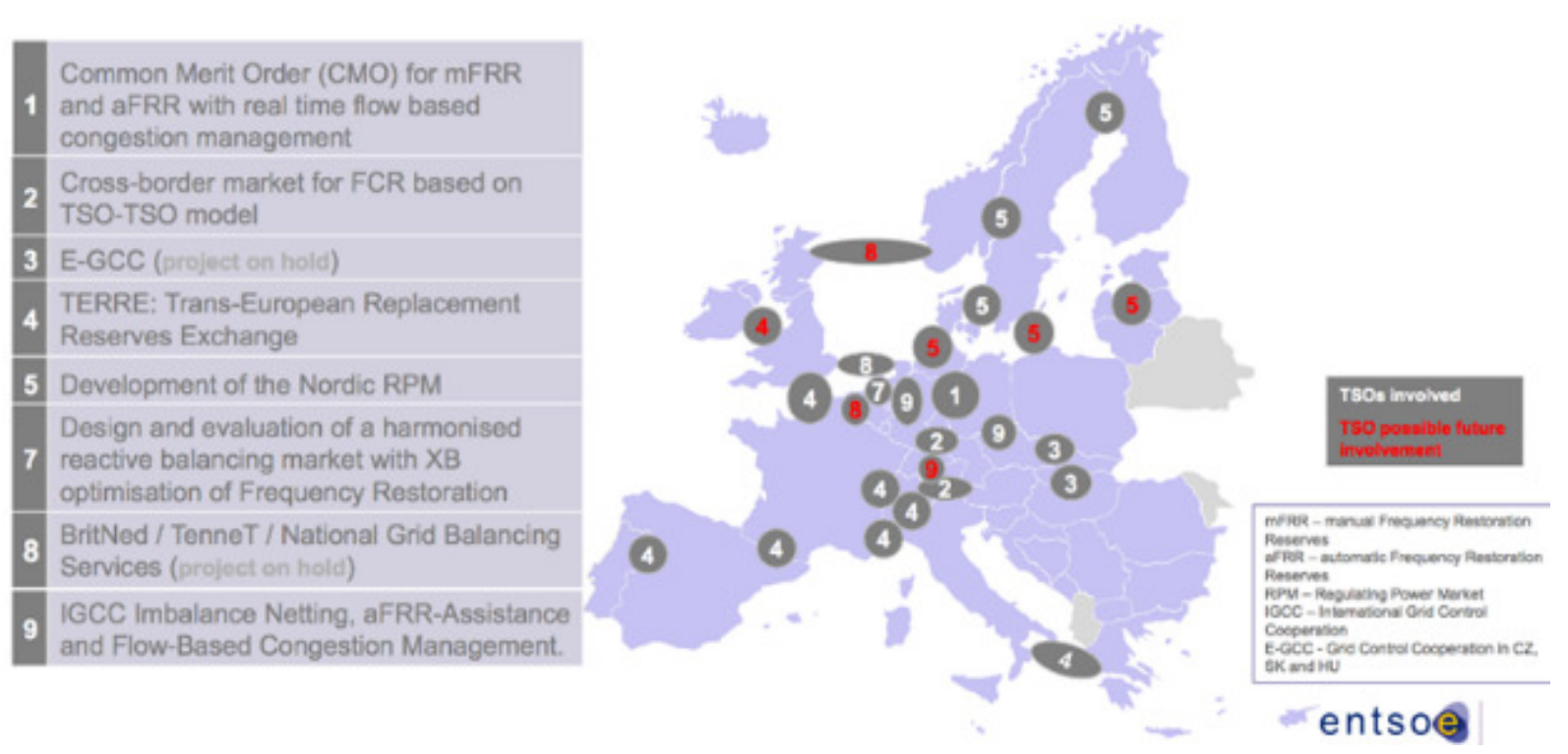

Fig. 1 - Overview of pilot projects on cross border trade in balancing markets, ENTSO-E [19]

\section{FREQUENCY SUPPORT PROCUREMENT PRACTICES IN THE REPUBLIC OF MACEDONIA}

The FS services in the $\mathrm{Re}^{*} 4 \mathrm{~b} 35 \mathrm{c}$ 6f Macedonia are defined in the national Network Code [20] established by the Macedonian TSO MEPSO. As a member of ENTSO-E, MEPSO should synchronize the rules with the ENTSO-E Network Code. However, the new changes from [1] have not been adapted yet.

The reserves are still defined according to [4] and include primary, secondary and tertiary reserve for primary, secondary and tertiary frequency regulation. MEPSO is responsible for the procurement of these reserves. These reserves are needed mostly due to the imbalances caused from conventional power plants.

The primary reserve is released automatically through the speed regulators of the turbines after a deviation of the frequency has occurred.

The primary reserve share is determined based on the generation in Macedonia compared to the whole interconnected system. The reference incident in the interconnected system is set on $3000 \mathrm{MW}$, and currently the share for Macedonia is approximately $\pm 8 \mathrm{MW}$, symmetrically in both directions [3].
This reserve should be activated within seconds after deviation of frequency has been noticed. A deviation higher than $\pm 20 \mathrm{mHz}$ should occur for the primary reserve to be released. The full primary reserve should be activated if the deviation of frequency is $\pm 200 \mathrm{mHz}$.

After the frequency has been contained to a quasi-stationary value by the primary reserve, the secondary reserve should be activated to return the frequency to its nominal value of $50 \mathrm{~Hz}$. This reserve is activated automatically.

The secondary reserve is determined with (1), where $P_{s o c_{i} i}$ is the secondary power reserve and $L_{m a x, i}$ is the peak load in area $i$ and the coefficients $a$ and $b$ are set empirically at $10 \mathrm{MW}$ and 150 MW.

$$
P_{\text {sec }, i}=\sqrt{a L_{\max . i}+b^{2}}-b
$$

The amount of secondary reserve is currently $\pm 41 \mathrm{MW}$.

The tertiary reserve is a manually activated reserve that is used to release secondary reserve in a case of a big incident. This reserve should be activated in 15 minutes after an incident and should be sustained for up to several hours. 
The amount of tertiary reserve that MEPSO must acquire, should be able to cover the disconnection of one generation block from TEC Bitola, i.e. $+205 \mathrm{MW}$, or the disconnection of the consumer with the highest power consumption directly connected to the grid, i.e. $-100 \mathrm{MW}$ [3].

MEPSO is obliged to obtain at least $50 \%$ of the total secondary and tertiary reserve within its control area. Up to $34 \%$ of the secondary reserve can be obtained from sources outside of its control area [20].

The primary reserve is a mandatory service for all hydro power plants with rated power higher or equal to $10 \mathrm{MW}$ and all thermal power plants with rated power higher or equal to $30 \mathrm{MW}$. The generators must have turbine regulators that can provide this service to be connected to the grid [20]. In addition, the smaller power plants should provide this service if this is requested from MEPSO.

Secondary and tertiary reserve capacities are procured by contracts with ELEM [21], the largest owner of power plants in the Republic of Macedonia. The services are remunerated with a lump sum that does not consider the real reserved capacity or use of energy [3].

\section{Recommendations for improvement and challenges for frequency support market development}

Based on the trends seen in European countries and the current conditions in Macedonia, there are several recommendations that can be made:

- Update the current Network Code to harmonize reserve products according to [1]. This is important for further development of procurement methods and cross border reserve exchanges.

- Keep the primary reserve mandatory and unremunerated. The needed capacity for this reserve is low and it is not expected to increase severely in near future.

- Change the procedure for secondary and tertiary reserves procurement. Before considering a development of a FS market for these services, it is important to shorten the contract periods for these reserves to less than a year, preferably on half-yearly or monthly basis. Also, the remuneration process must consider both capacity payment and used energy payment. This would prove more financially beneficial for both MEPSO and ELEM.
- Re-evaluate the necessary secondary and tertiary reserves ideally every month, or at least every 6 months. This would be necessary for the suggested changes in the procurement procedure.

- Evaluate the possibilities for cross-border exchange of reserves within the SMM (Serbia Montenegro - Macedonia) block in terms of cross-border capacities and available generation units. Sharing of reserves would further decrease the necessary reserves.

Ideally, the next step would be a FS market development. This would further lead to establishment of common balancing market in the region that would eventually join the European balancing market. This integration would reduce the reserves needed for balancing as much as possible and improve the system stability. However, there are many challenges to consider first.

FS markets in Europe are established only in countries where mature electricity markets exist. Therefore, a crucial step before considering creation of FS market is establishing a fully liberalised electricity market. The electricity market in Macedonia has not been fully liberalized yet. The full liberalization was anticipated to happen by $31^{\text {st }}$ December 2014. However, this has been postponed up to 2020. Currently, the Macedonian electricity market consists of a regulated and a liberalized segment. In the liberalized segment participate producers, suppliers and traders of electricity on one side, large and medium industry consumers on the other side. Small industry consumers and households are part of the regulated segment. Republic of Macedonia is a small market and ELEM owns $96 \%$ of the power plants. Thus, establishing a competitive market solely for Macedonia can be very hard. Better conditions could be expected if a joint FS market is developed within the SMM block. For the development of such market, it is of crucial importance to align national regulatory frameworks and make a detailed evaluation of the availability of cross-border capacities.

\section{CONCLUSION}

This research focuses on evaluating the current trends in Europe and the Republic of Macedonia for FS services procurement. It gives an overview of the changes in the network codes of ENTSO-E and provides a brief summary of the FS services and procurement methods of several CE 
countries. Furthermore, it analyzes the current conditions in the Republic of Macedonia and provides several recommendations for its improvement. In terms of FS market development in Macedonia, the research shows that the best option is to consider development of a joint FS market within the SMM block.

\section{REFERENCES}

[1] ENTSO-E, Network Code on Load Frequency Control and Reserves (LFCR), 2013.

[2] ENTSO-E, "Cross Border Electricity Balancing Pilot Projects," 2016. [Online]. Available: https://www.entsoe.eu/ major-projects/network-code-implementation/cross-borde r-electricity-balancing-pilot-projects/Pages/default.aspx.

[3] D. Bajs and M. Atanasovski, Студија за проценка на вкупните трошоци за интегрирање на ОИЕ во ЕЕС на Македонија (Study for estimating expenses from integration of RES in the power system in Macedonia), 2017.

[4] Continental Europe Operation Handbook, [Online]. Available: https://www.entsoe.eu/publications/system-operation s-reports/operation-handbook/Pages/default.aspx.

[5] System Operation Agreement, ENTSO-E, 2006.

[6] ENTSO-E, System Operation Guideline, 2016.

[7] H. Holttinen, A. Ivanova and J. L. Dominguez-Garcia, "Wind Power in Markets for Frequency Support Services", In: 13th International Conference on European Energy Markets (EEM16), Porto, Portugal, 2016.

[8] Primary Control Reserve in the Netherlands, [Online]. Available: https://www.regelleistung.net/ext/static/prlnl;js e ssionid=64D23796F78940C6F6382A06D5B7188D.

[9] Primary Control Reserve, [Online]. Available: https:// www.regelleistung.net/ext/static/prl.
[10] Elia System Operator, Regles de functionnement du marche relatif a la compensation des desequilibres quartharaires - Entre en vigueur partiellement en 2015 et intéralement a partir du 1er Janvier 2016," [Online]. Available: http://www.elia.be/ /media/files/Elia/Products-andservices/Balancing/20150825_R\%C3\%A8gles_Balancing _FR.pdf.

[11] Implementation Guide, 2012. [Online]. Available: http:/ /www.tennet.org/english/images/120214\%20SO\%20SOC $\% 2012$-xxx\%20Uitvoeringsregels $\% 204 \% 202 \% 20 \% 20 \mathrm{UK}$ clean_tcm43-19026.pdf.

[12] The Secondary Reserve: A Solution to Restore Balance and Frequency, [Online]. Available: http://www.elia.be/ /media/files/Elia/Products-and-services/ProductSheets/S - Ondersteuning-net/S2_F_RES_SECOND.pdf.

[13] Secondary control reserve, [Online]. Available: https:// www.regelleistung.net/ext/static/srl.

[14] H. Holttinen, J. Kiviluoma, N. Cutululis, A. Gubina, A. Keane and F. Van Hulle, "D2.2, REserviceS, Ancillary Services," 2012.

[15] Rules on Balancing - Portugal, [Online]. Available: https: //transparency.entsoe.eu/balancing-domain/r2/rulesOnBal anc ing/.

[16] Tertiary Production Reserve: A Solution to Major Imbalances and Congestion, [Online]. Available: http://www. elia.be/ /media/files/Elia/Products-and-services/Producth eets/S-Ondersteuning-net/S3_F_RES_TERT_PROD.pdf.

[17] Minute reserve, [Online]. Available: https://www.regellei stung.net/ext/static/mrl.

[18] I. d. 1. Fuente, Ancillary Services in Spain: Dealing with High Penetration of RES.

[19] Cross Border Electricity Balancing Pilot Projects, [On line]. Available: https://www.entsoe.eu/Documents/Netw ork\%20codes\%20documents/Implementation/Pilot_Proje cts /pilot_projects_map.png.

[20] MEPSO, Мрежни правила (Network Code), 2015.

[21] "ELEM," [Online]. Available: http://elem.com.mk/. 
